\title{
浅層改良を併用したラフト基礎 工法の開発と施工例
}

\section{DEVELOPMENT OF RAFT FOUNDATION WITH SHALLOW IMPROVEMENT AND ITS EXAMPLES OF CONSTRUCTION}

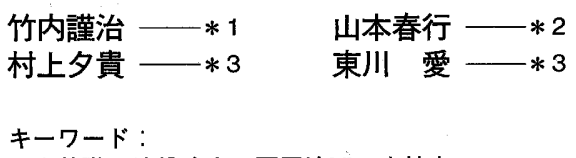

Keywords :

Raft foundation, Soil improvement, Differential settlement, Bearing capacity
Kinji TAKEUCHI $\rightarrow * 1$
Haruyuki YAMAMOTO - $* 2$
Yuki MURAKAMI $-* 3$

This paper presents a new shallow foundation system with soil improvement. As the new raft foundation system without pile is the hybrid building foundation with concrete raft and shallow soil improvement, it is an economical foundation. As the adoption of the new raft foundation system is able to reduce the excavating soil and concrete materials, it can be used as an environment-friendly foundation. This paper also reports the examples of actual constructed structure with the new raft foundation system and the measurement data of the settlement of the structure are reported too.

\section{1.はじめに}

軟弱地盤上に構造物を構築する場合、支持杭基礎工法を用いるか 深層改良による地盤改良基礎工法、あるいはべ夕基礎と摩擦杭を併 用したパイルドラフト基礎工法が用いられている ${ }^{1)}$ 。しかし、支持 杭基礎工法では周辺地盤の沈下が進行しても構造物自身は下がら ないため周辺地盤との段差が生じる抜け上がり現象が発生する。ま た、支持杭基礎工法や哚層改良による地盤改良基礎工法では、軟弱 層が非常に厚い場合には適用困難である。さらに、軟弱地盤におけ る支持杭基礎工法・深層改良による地盤改良基礎工法・パイルドラ フト基礎工法ともに低層の構造物に対しては相対的に高価であり 不経済な基礎工法となる場合が多く、これらの課題を解決する基礎 工法の開発が望まれる。このような状況に対して、本報告では、軟 弱地盤における構造物の不同沈下ならびに抜け上がりを抑制する ことが可能であり、かつより経済的な低層構造物の基礎工法を提案 し、その施工例ならびに沈下計測結果を示す。

\section{2. 浅層改良を併用したラフト基礎工法の概要}

地盤改良工法である ${ }^{2-6)}$ 。改良された地盤も基礎と考えることによ り、改良体の剛性を高めることで、従来必要とされていた地中梁を 省略することもできる。井桁状に改良することで、地中応力を集中 させることなく、分散化できる。また、構造物下の地盤の囲い込み 効果により、沈下を抑制すると共に、地震時の液状化対策にも有効 と思われる。図 1 に本基礎工法による基礎の概念図を示す。

\section{3. 浅層改良を併用したラフト基礎工法よる施工例}

表 1 に、本基礎工法を採用した建物の概要を、図 $2 \sim 4$ にそれぞ れの概要図を示す。表 1 から分かるように、どの建物も低層で比較

表 1 浅層改良を併用したラフト基礎工法による建物の概要

\begin{tabular}{|c|c|c|c|c|}
\hline 建物名 & 建設地 & 竣工時期 & 構造 & 施工面積 $\left(\mathrm{m}^{2}\right)$ \\
\hline Wスーパーマーケット & 岡山県玉野市 & H15. 8 & S 造平屋建 & 3,804 \\
\hline Mショップ & 広島県福山市 & H17. 4 & S 造平屋建 & 674 \\
\hline Hドラック゚ストアー & 広島県楅山市 & H17. 4 & $\mathrm{~S}$ 造平屋建 & 1,039 \\
\hline
\end{tabular}

この工法は地盤を井桁状に改良し、ベタ基礎と組み合わせた浅層

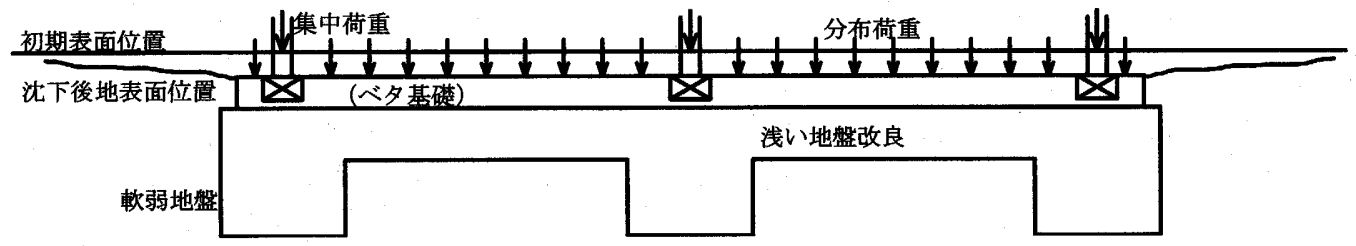

図 1 浅層改良を併用したラフト基礎工法による基礎の概念図

\footnotetext{
*1 株ティーアンドピィー設計事務所 代表取締役

(干723-0015 広島県三原市円一町4-2-14)

*2 広島大学大学院国際協力研究科 助教授・工博

*3 株ティーアンドピィー設計事務所 所貝
}

*1 President, T\&P Architect Engineers' Office Co., Ltd

*2 Assoc. Prof., Hiroshima University, Dr. Eng.

*3 Designer, T\&P Architect Engineers' Office Co., Ltd. 


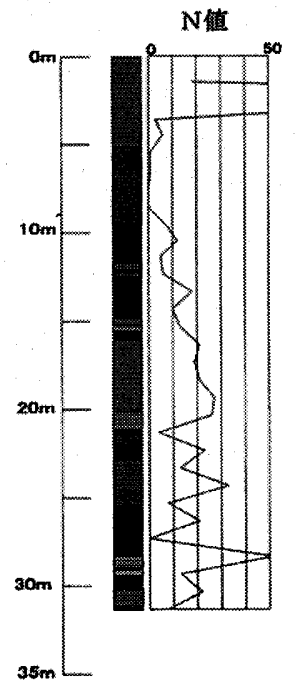

(a)土質柱状図

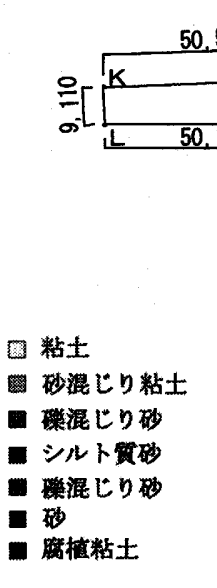

(b) 平面図
$15.420,22,000,12.775,16,30016,300$

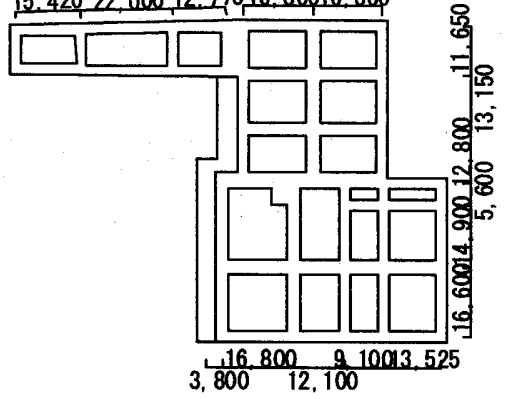

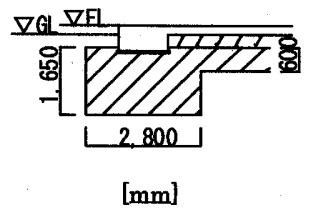

（c）地盤改良図

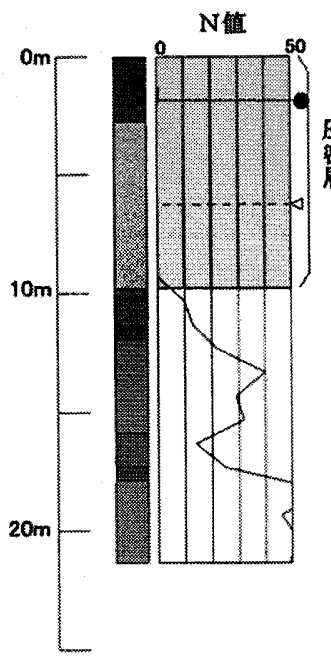

(a)土質柱状図

図 2 Wスーパーマーケット 概要図

一軸圧縮強さ $q u=20.6 \mathrm{kN} / \mathrm{m}^{2}$

圧維指数 $\mathrm{Cc}=1.482$

圧密降伏応力 $P c=65.52 \mathrm{kN} / \mathrm{m}^{2}$
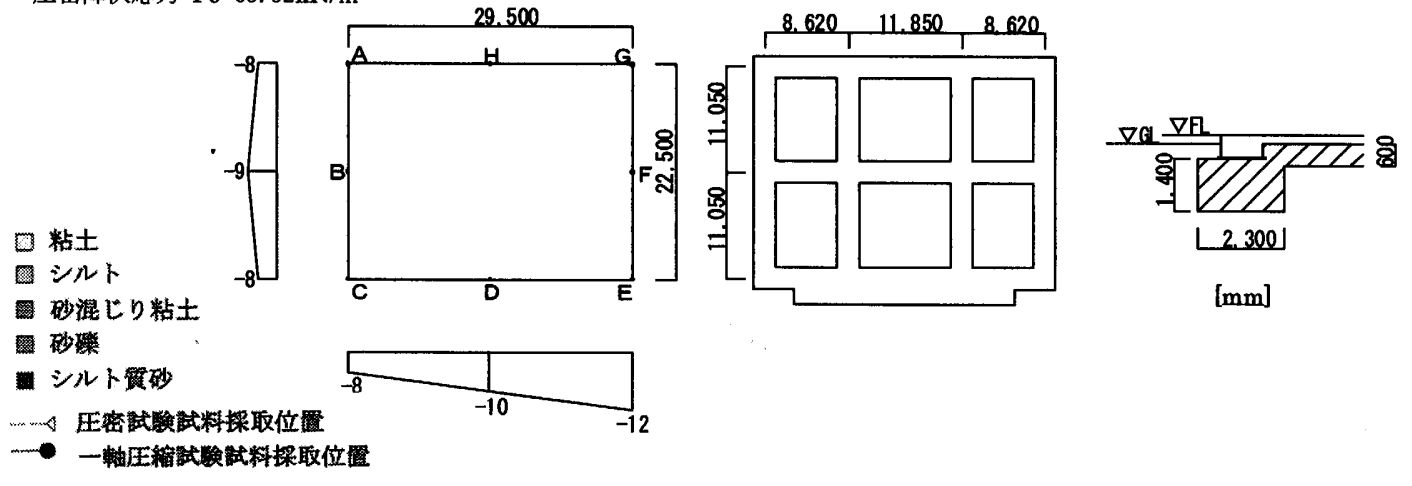

图 础混しり粘土

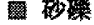

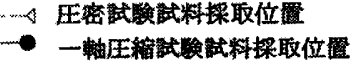

(b) 平面図

(c) 地盤改良図

図 3 Mショップ 概要図

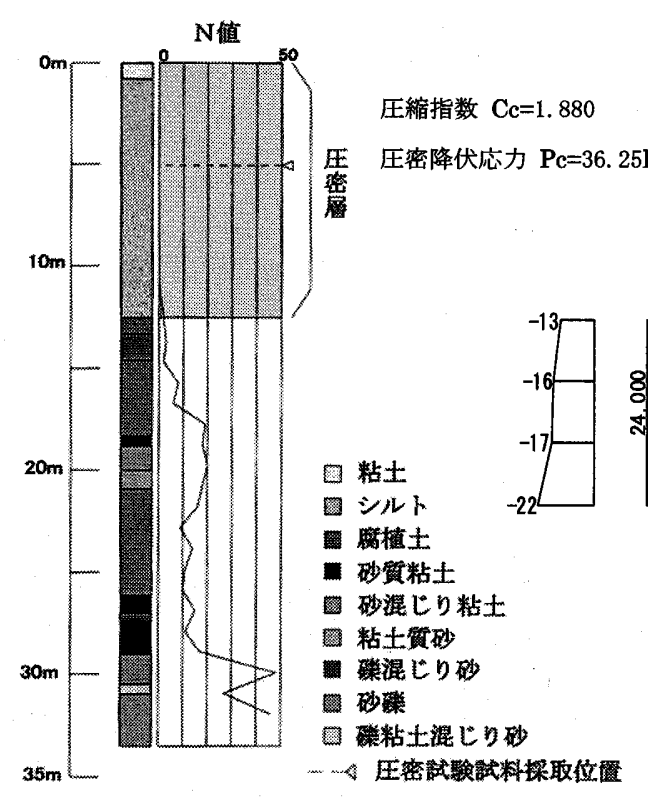

(a) 土質柱状図

(b) 平面図

（c）地艋改良図

図 4 Hドラッグストアー 概要図 


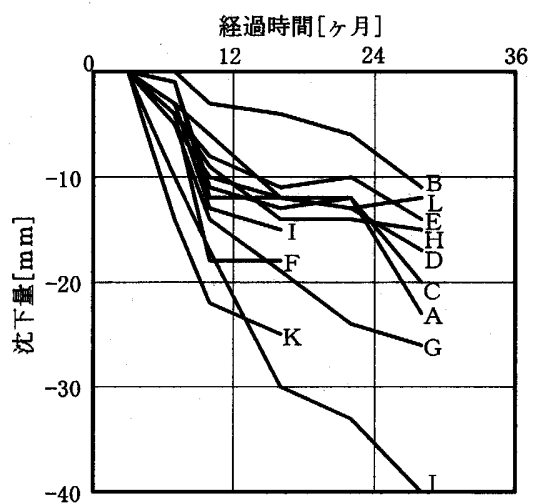

(a) 沈下測定結果

$\left[\mathrm{kN} / \mathrm{m}^{2}\right]$

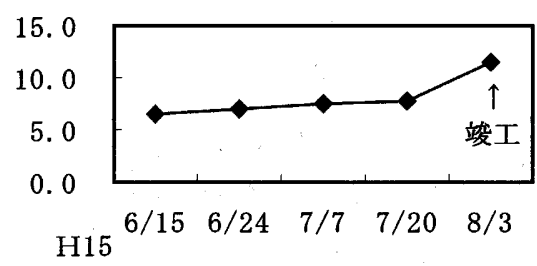

（b）荷重載荷時期と載荷重量

図 5 Wスーパーマーケット

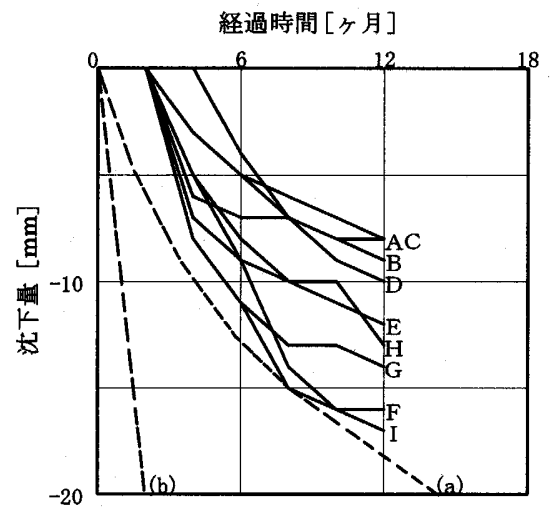

(a) 沈下測定結果

$\left[\mathrm{kN} / \mathrm{m}^{2}\right]$

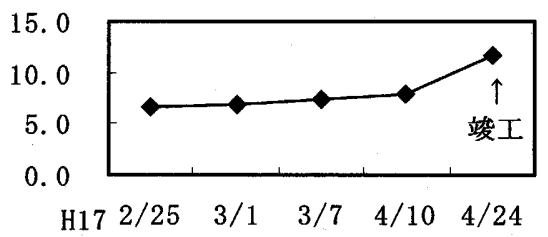

(b) 荷重載荷時期と載荷重量

図 6 Mショップ

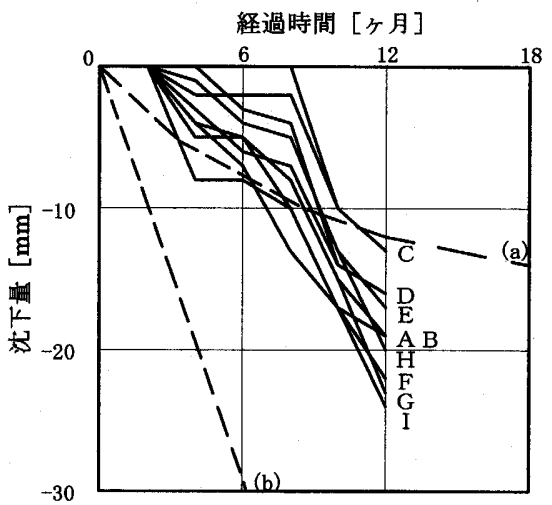

(a) 沈下測定結果

$\left[\mathrm{kN} / \mathrm{m}^{2}\right]$

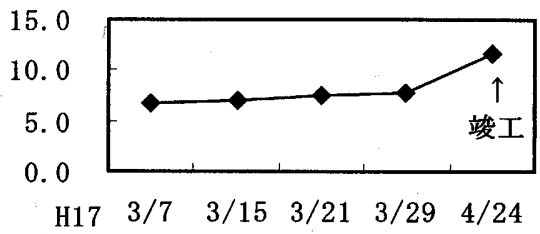

（b）荷重載荷時期と載荷重量

図 7 Hドラッグストアー
的面積規模が大きく、後述のように単位面積当たりの荷重が小さい。 しかし、図 2〜4のそれぞれの土質柱状図に示すように（圧密試験 や、一軸圧縮試験を行ったものについては、それらの結果を同図中 に示している。）、これらの建物が建つ地盤はかなり軟弱で、杭工法 を用いた場合、地盤沈下のため杭の抜け上がり等による地盤沈下障 害の可能性がある。特に、Mショップと Hドラッグストアーの地盤 は、河川の後背湿地にあった水田の跡地であり、表層から 10 数 $\mathrm{m}$ の深さまで粘土が堆積しており、この間のN值はほぼ0であった(サ ンプラーが自沈)。このような地盤では低層の比較的軽い構造物と はいえ、浅い独立基礎や布基礎の適用は困難であり、通常のべ夕基 礎を採用すれば全体に占める基礎そのものの重量が相当に大きく なり、さらに沈下量を増大せしめることになる。そこで、直下に浅 い地盤改良体を設置し、その上のべタ基礎の厚さを半分程度に減じ 得る本基礎工法を適用した。また、それぞれの建物における柱通り 直下の地盤改良層の厚さは、基礎底面に作用する接地圧が改良体に よる応力分散效果によって低減され、その応力が下部地盤の許容支 持力以下になるように設計した。その他の部分の改良体層厚は、W スーパーマーケット、Mショップに比べて、Hドラッグストアーの 方が厚くなっており、これは、長辺方向のスパンが 2 倍程度になっ ているためである。地盤改良の方法は浅層混合とし、目標強度は $100 \mathrm{kN} / \mathrm{m}^{2}$ 以上、セメント添加量は $100 \mathrm{~kg} / \mathrm{m}^{3}$ とした。なお、改良体 の 4 週圧縮强度試験を行ったところ、Wスーパーマーケットの場合

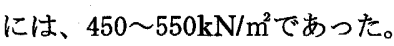

\section{4. 施工建物の沈下計測}

本基礎工法を適用した建物の沈下計測を計画し、竣工後レベル計 測を開始した。その後、ほぼ 2 ヶ月に 1 度の頻度で計測を継続して いる。沈下計測点は、図 $2 \sim 4$ のそれぞれの建物平面図に示す英字
記号の位置に設定している。なお、MショップとHドラッグストア 一においては、平面図の周囲の一部に、現時点における最終計測時 の沈下分布図を示す。不動点は支持杭基礎で支持されている近隣の 構造物に設置しているが、これらの杭基礎支持構造物はかなり抜け 上がり、Hドラッグストアーの近隣建物は、前面道路との段差が生 じている。周辺状況から、当地域における地盤沈下はほぼ収束して いると思われ、今回のレベル測量による沈下は主に建物荷重増によ るものと考えられる。

それぞれの建物の沈下計測結果を、図 $5 \sim 7$ に示す。なお、同図 中には、竣工までの載荷重履歴も併記している。これらの沈下計測 結果によれば、竣工後一年目あるいは二年目の時点で沈下が進行中 であるが、それぞれの計測点で全沈下量証数 cm 以内に収まってお り、また外見検査によってもまったく異常は無い。また、圧密試験 が実施されているものについては（MショップとHドラッグストア 一)、構造物の剛性等を考慮しない簡便な一次元圧密沈下計算を行 っている（建物中心位置の沈下量: 図 6,7 中の(b) と隅角部の沈下 量: 図 6,7 中の (a))。その場合、荷重は等分布荷重とし、荷重が加 わった時期は、工期の中間時点として沈下計算を行った。压密試験 結果によれば、これらの地盤は若干過圧密であったが、竣工後一年

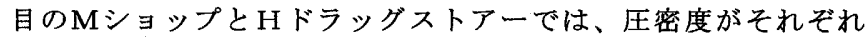
$\mathrm{U}=65 \%$ と $37 \%$ となる。したがって、建物中心位置の最終全沈下量は、 $\mathrm{M} シ ョ ッ フ ゚: 8.5 \mathrm{~cm}$ と H ドラッグストアー: $11.7 \mathrm{~cm}$ と計算上は推定さ れるが、竣工後一年目の沈下計測の傾向によるとそれらよりも小さ くなるものと考えられる。ただし、計測值は圧密沈下計算值(工期の 中間時点を起点)よりも小さくなっているが、計測開始時期が圧密計 算時期よりも約 2 ヶ月遅れていることが主な原因と考えられる。

さらに、表 2 ならびに表 3 に示すように、これらの建物について は沈下計測結果および前述の簡便な一次元圧密沈下計算による相 
表 2 Mショップ 相対変形角

\begin{tabular}{|c|c|c|c|c|}
\hline \multicolumn{2}{|c|}{} & $\mathrm{E}$ 点 & $\mathrm{F}$ 点 & $\mathrm{D}$ 点 \\
\hline \multirow{2}{*}{ 沈下量 $[\mathrm{cm}]$} & 計測値 & 1.2 & 1.6 & 1.0 \\
\cline { 2 - 5 } & 計算值 & 1.80 & 3.26 & 3.25 \\
\hline \multirow{2}{*}{$\mathrm{E}$ 点との差 $[\mathrm{cm}]$} & 計測值 & - & 0.4 & 0.2 \\
\cline { 2 - 5 } & 計算值 & - & 1.46 & 1.45 \\
\hline \multirow{2}{*}{ 相対変形角 $\left[\times 10^{-3} \mathrm{rad}\right]$} & 計測値 & - & 0.27 & 0.18 \\
\cline { 2 - 5 } & 計算值 & - & 0.99 & 1.29 \\
\hline
\end{tabular}

表 3 Hドラッグストアー 相対変形角

\begin{tabular}{|c|c|c|c|c|}
\hline \multicolumn{2}{|c|}{} & $\mathrm{C}$ 点 & B 点 & D 点 \\
\hline \multirow{2}{*}{ 沈下量 $[\mathrm{cm}]$} & 計測值 & 1.3 & 1.9 & 1.6 \\
\cline { 2 - 5 } & 計算値 & 1.26 & 2.53 & 2.45 \\
\hline \multirow{2}{*}{ 点との差 $[\mathrm{cm}]$} & 計測值 & - & 0.6 & 0.3 \\
\cline { 2 - 5 } & 計算值 & - & 1.27 & 1.19 \\
\hline \multirow{2}{*}{ 相対変形角 $\left[\times 10^{-3} \mathrm{rad}\right]$} & 計測值 & - & 0.30 & 0.38 \\
\cline { 2 - 5 } & 計算值 & - & 0.61 & 1.49 \\
\hline
\end{tabular}

対変形角の検討も行っている。表中の各点は、図 3 ならびに図 4 中 の沈下計測点であり、隅角点と隣接する計測点との沈下差ならびに その間の相対変形角を示している。なお、上段が計測值によるもの であり、下段が簢便な一次元圧密沈下計算によるものである。これ らの表より、いずれも竣工後一年目の相対変形角は小さく、構造上 の問題は無いことが分かる。

\section{5. まとめ}

軟弱地盤における構造物の不同沈下ならびに抜け上がりを抑制
することが可能であり、かつより経済的な低層構造物の基礎工法の 開発を目指し、浅層改良を併用したラフト基礎工法を提案した。本 基礎工法の特徴は、軟弱地盤の表層を浅く改良し、その上のベタ基 礎と組み合わせる構成にある。本基礎工法による施工工事ならびに 沈下計測結果について報告した。今後、さらに沈下計測を継続して 安全性を確認するとともに、圧密沈下に基づく不同沈下の検討に基 礎や構造物の剛性効果を取り入れることや、井桁状に改良すること による地盤の囲い込み効果について検討し、より合理的な基礎工法 へ進展させたいと考えている。

\section{台考文献}

1）茶谷文雄（監修）：支持杭基喏から多様な基礶へ，建築技術, No. 656, pp. $91-178,2004.9$

2）李 倬（他）: 浅層地盤改良べ夕基喽工法の不同沈下抑制効果に関する解 析的研究，日本建築学会中国支部研究報告集，第 28 巻, pp. 133-136, 2005. 3 3）山本春行（他）: 浅層地盤改良を併用したベタ基䂵の沈下举動解析, 第 40 回地盤工学研究発表会報告集, pp. 1499-1500, 2005.7

4）李 偉（他）: 数值解析による井析型浅層地盤改良べ夕基礴の沈下性状に ついての検討, 建築学会大会学術講演梗概集, 構造 I (B- I ), pp. 779-780, 2005.9

5) H. Yamamoto et al., A new raft foundation system with shallow soil improvement, Proc. of the 3 th international structural engineering and construction conference (ISEC-03) SHUNAN, JAPAN, pp. 797-804, 2005.9 6) Wei Li et al., Effect of raft foundation with shallow soil improvement on controlling differential settlement, Proc. of the Second China-Japan geotecnical symposium, SHANGHAI, CHINA, pp. 350-357, 2005. 10

[2006年 4 月20日原稿受理 2006年 7 月27日採用決定］ 